\title{
A STUDY REVIEW OF ACTIVE LEARNING STRATEGY IN IMPROVING STUDENTS' LEARNING MOTIVATION
}

\section{Ubabuddin $^{\text {a) }}$}

a) Sultan Muhammad Syafiuddin Sambas Islamic Institute, Jl. Raya Sejangkung No. 126 Sebayan-Sambas Higher Education Complex, West Kalimantan, E-mail: ubabuddin@gmail.com

\begin{abstract}
ABSTRACK
Scope: Learning approaches that are considered effective and feasible to be applied in the current learning process are active learning strategies. By using an active learning strategy, students will be invited to always be involved and motivated to do their best in each learning process, so that students will become excited in participating in learning. Objective: This qualitative study presented the results of literature reviewed gathering from various theories, including national, international journals, books, internet and other literature to answer the problem formulation. Method: A serial of literature on active learning strategies that actively applied in most modern education were reviewed and presented to answer the research question. Findings: based on many experts in the fields of teaching and learning, the findings of this study were First, Active learning starts with questions, card short, the power of two, jigsaw, Index card match, picture and picture, cooperative script, problem based instruction, students team achievement devision, etc. Significance: The findings of this literature rewiewing has promoted students better thoughtful and understanding on material presented as participants engaging themselves with the lesson cores not simply just follow teacher's instruction. These findings are also so useful insight to keep student's concentration and improving learning achieving to the higher learning outcomes as demanded by instructional curriculum. Recomendation: Monotonous and teacher-focused learning is increasingly in demand and continues to be abandoned because it makes students bored and boring. With an effective approach it is hoped that learning objectives can be optimally achieved.
\end{abstract}

Keywords: Learning Motivation, Strategy, Active Learning

\section{A. Introduction}

Learning basically as an effort in motivating students into the learning process, so students get knowledge, experience and skills in accordance with the objectives of learning. Learning is a modification process in human capacity that can be maintained and increased at a level. ${ }^{1}$ While Miftahul Huda provides a definition of learning as an effort to facilitate teachers, instructors, teachers and lecturers so that students can learn easily. Learning activities will result in students learning something more effectively and efficiently. Therefore, the learning process should pay attention to the differences in the individual character of each student, so that learning can really change the condition of students who do not know to know, from

\footnotetext{
${ }^{1}$ Sa'dun Akbar, Instrumen Perangkat Pembelajaran (Bandung: Remaja Rosdakarya, 2013), 45.
} 
those who do not understand to understand, as well as from behavior that is not or is not good to be good.

The use of learning strategies and methods that vary in conveying material to students will increase the motivation of students in participating in the learning process, thereby making it easier for students to follow, learn, and understand the material delivered. Learning strategies can be interpreted as a plan that contains a series of activities designed to achieve certain educational goals. While, strategy is a plan of action including the use of methods and utilization of various resources or strengths in learning that are structured to achieve learning.

Effective learning will be obtained if the teaching and learning process can achieve learning objectives in accordance with the plan. Learning is said to be effective if a teacher can use appropriate and varied strategies and methods according to the material to be delivered. So, a professional educator must master a number of diverse strategies and methods and be able to apply them in the field. Therefore, this study used literature by gathering various theories, including national, international journals, books, internet and other literature to answer the problem formulation. ${ }^{2}$

\section{B. Active Learning Strategies}

Learning strategies are efforts to create conditions intentionally so that learning objectives can be facilitated in their achievement. Miarso is of the view that the learning strategy is a comprehensive approach in a learning system in the form of guidelines and a framework of activities to get closer to achieving the learning objectives. Learning strategies include nine activities in learning, namely: (1) attracting the attention of students, (2) providing information on learning objectives for students, (3) repeating learning to ensure students master it, (4) giving instructions on how to learn effective material, (5) providing stimulus, (6) showing understanding to students related to the material that has been delivered (7) giving feedback related to the level of understanding of students, (8) giving an assessment, and (9) giving a conclusion.

Strategy is a tool in the teaching and learning process that occurs the interaction of teachers and students to achieve learning goals. ${ }^{3}$ As for what is meant by active learning according to Febrian, ${ }^{4}$ is an effort to foster creativity so that it can foster innovations.

While active learning or active learning is any form of learning that allows students to play an active role in the learning process. In the book Active Learning Strategies by Hisham

\footnotetext{
2 Aslan, "Pumping Teacher dalam Tantangan Pendidikan Abad 21" 2, nomor 2 (2017): 89-100.

${ }^{3}$ Hasibuan dan Mudjiono, Proses Belajar Mengajar (Bandung: Rosdakarya, 2000), 3.

${ }^{4}$ Febrian, Manajemen Pelatihan Berbasis Belajar Mandiri (Yogyakarta: Pustaka Pelajar, 2000), 11.
} 


\section{Ubabuddin}

Zaini, ${ }^{5}$ active learning is a learning that invites students to learn actively. Because with active learning, students will be able to solve their own problems and most importantly do their work according to the knowledge they have. Learning strategies chosen by teachers should be based on various considerations in accordance with the situation, conditions and environment that will be faced. Selection of learning strategies generally starts from: 1) Formulation of learning objectives that have been set, 2) Analysis of the needs and characteristics of students produced, and 3) Types of subject matter to be communicated.

From some of the above opinions it can be concluded that learning strategies as the methods chosen and used by an educator to deliver subject matter, so that it will make it easier for students to achieve the expected learning goals by using the best, appropriate and enjoyable approach. According to Melvin L. Silberman there are 101 types of active learning strategies, the following active learning strategies according to Silberman include:

\section{Learning Start With A Question}

a. Choose readings and share them with students

b. Asking students to study reading

c. Ask students to mark the reading in parts that are not understood

d. Participants write questions about the material being read

e. Gather questions that have been written by students

f. Deliver learning by answering these questions.

\section{Card Short}
a. Divide pieces of paper that contain information in one or more categories
b. Participants walk around the class to find the same category
c. Participants present the same category in front of the class
d. Provide important points related to the material

\section{The Power of Two}
a. Asking questions that require reflection and thought
b. Ask students to answer questions individually
c. Ask students to pair up and exchange answers and discuss them
d. Asking partners to make new answers to questions and improve their individual answers
e. Compare answers of each pair in the class

\section{Jigsaw Learning}

a. Select material into several segments

b. Divide students into groups

${ }^{5}$ Hisyam Zaini, Strategi Pembelajaran Aktif (Jakarta: PT. Gramedia Pustaka Utama, 2011). 
c. Each group gets the task of reading and understanding different material

d. Each group sends its members to other groups to convey what they have learned

e. Restore the classroom atmosphere as before

f. Give questions to check students' understanding of the material

\section{Index Card Match}

a. Make pieces of paper a number of students in the class

b. Divide the number of pieces of paper into two equal parts

c. Write questions about the material that has been given previously on half the paper that has been prepared. Each paper contains one question

d. On the other half of the paper, write the answers to the questions that have been made

e. Shake all the paper, so that it will be mixed with questions and answers

f. Each student is given one paper (it is explained to students that the activities carried out are in pairs, half the students get questions and the other half will get answers)

g. Ask students to find their partners. If you have found a partner, ask them to sit close together. Explain to them not to tell the material that they got to other friends

h. After all students find a partner and sit close together, ask each pair in turn to read questions and answers aloud to other friends.

i. End this process by making clarifications and conclusions

\section{Picture and Picture}

a. The teacher conveys the competencies to be achieved

b. Presenting material as an introduction

c. The teacher shows pictures related to the material

d. The teacher appoints students alternately to install or sort the pictures into a logical sequence

e. The teacher asks the reasons or rationale for the picture sequence

f. From the reason or sequence of the picture the teacher starts to embed the concept or material in accordance with the competency to be achieved

g. Conclusions or summary

\section{Cooperative Script}

a. The teacher divides students into pairs

b. The teacher distributes the discourse or material for each student to read and make a summary

c. Teachers and students determine who first acts as a speaker and who acts as a listener

d. The speaker reads the summary as complete as possible, by including the main ideas in his work, while the listener 


\section{Ubabuddin}

e. Listen to or correct basic ideas that are incomplete

f. Helps to remember or memorize the main ideas by connecting previous material or with other material

g. Changing roles, initially as a speaker is exchanged as a listener and vice versa. And do as above

h. Conclusion of teachers and students

\section{Problem Based Introductions}

a. The teacher explains the competencies to be achieved and mentions the supporting facilities or tools needed.

b. The teacher helps students define and organize learning tasks related to the problem (assigning topics, assignments, schedules, etc.)

c. The teacher encourages students to gather appropriate information, experiments to get explanations and problem solving, data collection, hypotheses.

d. The teacher helps students plan their work readiness accordingly

e. The teacher helps students to reflect or evaluate their experiments and the processes they use

\section{Student Teams Achievement Divisions (STAD)}

a. Forming groups with 4 heterogeneous members (mixed according to achievement, ethnicity, gender, etc.)

b. The teacher presents the lesson

c. The teacher gives assignments to the group to be done by group members.

d. The teacher gives questions or quizzes to all students.

e. Evaluate members

f. conclusions

10. Role Playing

a. The teacher prepares or prepares a scenario to be displayed

b. Appoint a number of students to study the scenario within a few days before KBM

c. Teachers form groups of students with 5 members each in each group

d. Provide an explanation of the competencies to be achieved

e. Calling students who have been appointed to play the scenario that has been prepared

f. Each student is in his group while observing the scenario being demonstrated

g. After completion of the presentation, each student is given a worksheet to discuss and comment on the performances of each group

h. Each group presents their conclusions

i. The teacher gives general conclusions 
j. Evaluation

k. Conclusion

\section{Snowball Throwing}

a. The teacher presents the material to be presented

b. The teacher forms groups and calls the leader of each group to give an explanation of the material

c. The chairman returns to his group and explains the material the teacher conveys to his friend

d. Then each student is given one sheet of work paper, to write down any questions related to the material that has been explained by the group leader

e. Then the paper containing the questions made into a ball and tossed from one learner to other learners for +15 minutes

f. After students get one ball or questions given the opportunity for students to answer the questions written on the ball-shaped paper alternately

g. evaluation

h. conclusion

\section{Inside-Outside Circle}

a. Half the class stands in a small circle and faces out

b. The other half of the class forms a circle outside the first circle, facing inward

c. Two students in pairs from small and large circles share information. This information exchange can be done by all pairs at the same time

d. Then students in the small circle are still in place, while students who are in the big circle shift one or two steps clockwise

e. Now the students' turn is in the big circle that shares information. And so on.

\section{Learning Motivation of Students}

The learning process will succeed according to the expected goals when students have a strong motivation in following the learning process. An educator needs to foster student motivation. To obtain optimal learning outcomes, educators are required to be creative in arousing students' learning motivation.

The term motivation comes from the Latin movere which is the same as to move in English tang means to move or push. According to Hasibuan, ${ }^{6}$ motivation is the driving force that creates excitement in carrying out something, which arises from the individual self and

\footnotetext{
${ }^{6}$ Hasibuan, Manajemen Sumber Daya manusia (Jakarta: Bumi Aksara, 2008), 65.
} 


\section{Ubabuddin}

from outside the individual. According to Mc Clleand in Mulyasa, ${ }^{7}$ motivation is the determining element that influences the behavior found in every individual.

From some of the above opinions it can be concluded that motivation is everything as a driving force that generates behavior activities of someone who comes from an individual person and others to achieve the desired goals. While learning motivation is the tendency of students to do all learning activities that are driven by a desire to achieve the best possible learning achievements or results.

Sardiman, ${ }^{8}$ revealed that learning motivation is a unique role as an arouser in each individual, as well as giving rise to a feeling of encouragement to learn. Students who have high motivation will have enthusiasm and lots of energy to carry out daily learning activities.

According to Djamarah, ${ }^{9}$ the motivation to learn in each individual can be different, so there are students who just want to avoid bad grades and even to avoid punishment from the teacher, and the orientation is only to get high grades, but there are also students who really want to develop insight and knowledge. Motivation comes from the first two directions of motivation that arise from within the individual or called intrinsic motivation, and motivation that comes from outside oneself is called extrinsic.

1. Intrinsic Motivation

Intrinsic motivation is things and circumstances that originate within the students themselves which can encourage action in learning, including: (a) the desire to become an expert and educated person, (b) learning accompanied by interests, (c) learning accompanied by feeling happy.

\section{Extrinsic Motivation}

Extrinsic motivation is an active and functioning impulse due to external stimuli. Learning motivation is said to be extrinsic when students place their learning goals outside of learning factors. Students learn because they want to achieve goals that lie outside those they learn. ${ }^{10}$ Learning should increase students' intrinsic learning motivation as much as possible. There are several ways to improve the intrinsic motivation of students:

a) Generating Interest in Learning

Generating the desire to know students about the lessons to be passed,

b) Encourage Curiosity

Evoking students' curiosity about what is happening, and so on

c) Using Variations of Interesting Presentation Methods

\footnotetext{
${ }^{7}$ Mulyasa, Dasar-Dasar Kompetensi Guru (Jakarta: Grasindo Persada, 2005), 145.

${ }^{8}$ Sardiman, Menjadi Komunitas Pembelajar (Jakarta: Bumi Aksara, 2011).

${ }^{9}$ Syaiful Djamarah, Strategi Belajar Mengajar (Jakarta: Rineka Cipta, 2012).

${ }^{10}$ Sardiman, Menjadi Komunitas Pembelajar. 
Intrinsic motivation for learning can be improved through the use of interesting learning materials

d) Assist Students in Formulating Learning Objectives

The basic principle of motivation in students is getting stronger to achieve goals if goals are set by themselves, the feeling of having learning goals will eventually give birth to an impulse to obtain them. ${ }^{11}$

\section{Conclusions}

Active learning is model of learning process that empowers all potentials of students to be able to learn through various activities of speaking, reading, writing, listening, and reflecting. Active learning requires dialogue with oneself and others and wants real experience and observation. Motivation can be interpreted as the strength of someone who can bring up the strength and willingness to carry out an activity. The learning process will run well and achieve goals optimally when students have motivation in learning. An educator is required to be able to increase motivation in following the learning process. With the active learning strategy approach, it will be easier for teachers to arouse students' motivation in learning. As explained above, some active learning strategies according to Melvin L. Siberman can be used by teachers in delivering learning material.

\section{Reference}

Akbar, Sa'dun. Instrumen Perangkat Pembelajaran. Bandung: Remaja Rosdakarya, 2013.

Anni, Catarina Tri. Psikologi Belajar. Semarang: UPT. Unnes Press, 2004.

Aslan. "Pumping Teacher dalam Tantangan Pendidikan Abad 21" 2, nomor 2 (2017): 89-100.

Djamarah, Syaiful. Strategi Belajar Mengajar. Jakarta: Rineka Cipta, 2012.

Febrian. Manajemen Pelatihan Berbasis Belajar Mandiri. Yogyakarta: Pustaka Pelajar, 2000.

Hasibuan. Manajemen Sumber Daya manusia. Jakarta: Bumi Aksara, 2008.

Hasibuan, dan Mudjiono. Proses Belajar Mengajar. Bandung: Rosdakarya, 2000.

Huda, Miftahul. Model-Model Pengajaran dan Pembelajaran. Yogyakarta: Pustaka Pelajar, 2013.

Miarso. Media Belajar dan Pembelajaran. Bandung: Remaja Rosdakarya, 2004.

Mulyasa. Dasar-Dasar Kompetensi Guru. Jakarta: Grasindo Persada, 2005.

Sardiman. Menjadi Komunitas Pembelajar. Jakarta: Bumi Aksara, 2011.

Silberman, Mel. Pembelajaran Aktif: 101 Strategi untuk Mengajar Apa Jua Subjek., Terj., Zainab Ahmad. Cet-4. Malaysia: ITBM, 2004.

Zaini, Hisyam. Strategi Pembelajaran Aktif. Jakarta: PT. Gramedia Pustaka Utama, 2011.

\footnotetext{
${ }^{11}$ Catarina Tri Anni, Psikologi Belajar (Semarang: UPT. Unnes Press, 2004), 136-37.
} 